\title{
EFFects of LARge-Scale Fire on Plant Regeneration on Subalpine Plateaus in Yellowstone National PARK
}

\author{
WILLIAM H. ROMME $\bullet$ DEPARTMENT OF BIOLOGY \\ FORT LEWIS COLLEGE $\bullet$ DURANGO
}

\author{
MONICA G. TURNER • ROBERT H. GARDNER ^ WILliAM W. HARgROVE \\ ENVIRONMENTAL SCIENCES DIVISION $\bullet$ OAK RIDGE NATIONAL LABORATORY \\ OAK RIDGE
}

\section{$\checkmark \quad$ INTRODUCTION}

The scale of the 1988 fires in Yellowstone National Park (YNP) raised numerous questions for the management of natural areas subject to large but infrequent natural disturbances. The central question that we have addressed in our postfire studies is whether the effects of large-scale fires, such as those in 1988 , differ qualitatively as well as quantitatively from effects of smaller fires. The answer to this question has important implications for our understanding of the evolution of natural systems and for management of future disturbances in places like YNP (Christensen et al. 1989). We approached this question on Yellowstone's extensive subalpine plateaus by comparing patterns of plant regeneration in large vs. small fire-generated patches after the 1988 fires. This research complements our work in northern YNP that focused on the landscape-level interactions among ungulates, vegetation, and fire, and was published in the UW-NPS Report for 1992 (Turner et al. 1992).

Recent research into the mechanisms of plant succession following fire or other disturbances has demonstrated that species responses may vary with different kinds and severities of disturbance and with the larger spatial and temporal context of the disturbance. For example, Rowe (1983) describes several species of boreal plants that resprout from surviving belowground structures after low-severity fires and dominate early successional stages; these same species are killed by severe fires and replaced by other species having greater dispersal abilities (also see Miller 1982, Malanson 1984, and Halpern 1989). The scale and heterogeneity of the 1988 Yellowstone fires provide an exceptional opportunity to evaluate the relative importance of the size and spatial patterning of fire-created patches for reestabishment of plant species representing different modes of reproduction.

\section{$\checkmark \quad$ STUDY AREA}

Our research was conducted on the subalpine plateaus that cover most of the southern, central, and western portions of YNP. Substrate is predominantly Quaternary rhyolites, basalts, and tuffs, except for the southeastern area (Two Ocean Plateau) which is underlain by Tertiary andesite (Keefer 1972). Mean elevation is ca. $2400 \mathrm{~m}$, and the climate is continental with cool short summers and long cold winters (Dirks and Martner 1982).

Large-scale fires have occured in the past on the high plateaus of YNP, e.g., in the early $1700 \mathrm{~s}$, and have shaped the vegetation mosaic that covers the area (Romme and Despain 1989). The 1988 fires burned some 300,000 ha in and around YNP (Despain et al. 1989). We recognized three burn severity classes in forested areas: (1) crown fire, in 
which all aboveground vegetation was killed, and the fire consumed all leaves and small twigs in the canopy, as well as the organic material on the forest floor; (2) severe surface fire, in which all aboveground vegetation was killed and most of the organic layer on the forest floor was consumed, but dead leaves and twigs remained in the canopy; and (3) light surface fire, in which the fire consumed a portion of the organic matter on the forest floor, but killed only a few trees and ground layer plants.

\section{$\checkmark \quad$ METHODS}

We established permanent sampling plots in 1990 in three contrasting study sites in the subalpine plateau study area. The sites were: (1) Cougar Creek site, located at low elevations on moderately fertile soils near the West Entrance of YNP; (2) Fern Cascades site, at high elevations on infertile soils near Old Faithful; and (3) Yellowstone Lake site, at high elevations on fertile soils near the South Arm of Yellowstone Lake. Within each site, we selected three patches of crown fire more-or-less randomly from the Park's fire map. Each site included a large (500-3500 ha), moderate (ca. $100 \mathrm{ha}$ ), and small (ca. $1 \mathrm{ha}$ patch, for a total of nine sample patches in the entire study area.

Each patch was located on the ground, and a pair of perpendicular transects established, extending from the center of the patch into the unburned (or lightly burned) surrounding area. Permanent sampling plots were located at variable intervals along the transects. Where the transect extended through a large expanse of the same burn severity class, plots were $100 \mathrm{~m}$ apart. As the transect approached an edge between two burn severity classes, the plots were placed closer together, e.g., at $10 \mathrm{~m}$ intervals, to detect edge effects. In each plot we recorded local slope, aspect, and burn severity; measured percent cover of bare soil, litter, herbs, shrubs, graminoids, and trees using eight $0.25-\mathrm{m}^{2}$ point-frame samples; measured density of selected species within the perimeters of the eight point-frames; and determined the number of plant species within a $10-\mathrm{m}^{2}$ portion of the plot. We also recorded numbers of individuals of less common opportunistic species within long belt transects extending between sample plots. These data were collected from each of the 898 permanent plots in the summers of 1990, 1991, 1992, and 1993. Patterns of regeneration were assessed by means of analysis of variance.

\section{$\rightarrow \quad$ RESULTS}

Data analysis is still in progress, but we can present some initial findings at this time. Biotic cover in the burned patches varied in a complex manner with study site, burn severity, patch size, and year; local site factors (slope, aspect) also were sometimes significant (Table 1). Analysis of variance revealed that study site, burn severity, and patch size were the most important main effects contributing to variability in total biotic cover. Total biotic cover increased through time in areas of crown fire or severe surface burn, and generally was greatest at the Cougar Creek and Yellowstone Lake study sites and lowest at the Fern Cascades site (Figure 1). In areas affected by crown fire, total biotic cover increased 24x between 1990 and 1993, and by 1993 ranged from $25 \%$ at Fern Cascades to nearly $50 \%$ at the other two study sites. Among burn severity classes, total biotic cover was lowest in crown-fire burns and greatest in the light surface burns. Total cover showed only a slight increase between years in areas affected by crown fire.

Table 1. Analyses of variance for percent cover of ground layer vegetation in burned patches from 1990-1993. Percent cover data were arc-sine-square root transformed before analysis.

Total Biotic Cover $\left(r^{2}=0.51\right)$ :

\begin{tabular}{|l|l|l|l|l|}
\hline SOURCE & DF & SUM OF SQUARES & F & P \\
\hline Year & 3 & 0.67 & 5.44 & 0.001 \\
\hline Site & 2 & 31.34 & 379.54 & 0.0001 \\
\hline Patch size & 2 & 4.49 & 54.40 & 0.0001 \\
\hline Burn severity & 3 & 11.77 & 95.01 & 0.0001 \\
\hline Slope & 1 & 0.40 & 9.66 & 0.002 \\
\hline Aspect & 2 & 1.08 & 13.11 & 0.0001 \\
\hline Site $x$ year & 6 & 2.01 & 8.10 & 0.0001 \\
\hline Burn $x$ year & 9 & 2.02 & 5.44 & 0.0001 \\
\hline Patch $x$ year & 6 & 0.37 & 1.50 & 0.175 \\
\hline
\end{tabular}

Tree Seedling Cover $\left(r^{2}=0.45\right)$

\begin{tabular}{|l|l|l|l|l|}
\hline SOURCE & DF & SUM OF SQUARES & F & P \\
\hline Year & 3 & 0.28 & 9.23 & 0.0001 \\
\hline Site & 2 & 14.03 & 693.25 & 0.0001 \\
\hline Patch size & 2 & 0.26 & 12.96 & 0.0001 \\
\hline Burn severity & 3 & 0.65 & 21.48 & 0.0001 \\
\hline Slope & 1 & 0.29 & 28.69 & 0.0001 \\
\hline Aspect & 2 & 0.12 & 5.80 & 0.003 \\
\hline Site $x$ year & 6 & 1.03 & 16.99 & 0.0001 \\
\hline Burn $x$ year & 9 & 0.11 & 1.19 & 0.30 \\
\hline Patch $x$ year & 6 & 0.04 & 0.65 & 0.69 \\
\hline
\end{tabular}


Forb Cover $\left(r^{2}=0.44\right)$ :

\begin{tabular}{|l|l|l|l|l|}
\hline SOURCE & DF & SUM OF SQUARES & F & P \\
\hline Year & 3 & 0.66 & 6.30 & 0.0003 \\
\hline Site & 2 & 27.33 & 389.86 & 0.0001 \\
\hline Patch size & 2 & 4.59 & 65.46 & 0.0001 \\
\hline Bum severity & 3 & 2.39 & 22.75 & 0.0001 \\
\hline Slope & 1 & 0.002 & 0.05 & 0.82 \\
\hline Aspect & 2 & 0.45 & 6.46 & 0.002 \\
\hline Site $x$ year & 6 & 4.08 & 19.40 & 0.0001 \\
\hline Bum $x$ year & 9 & 0.90 & 2.84 & 0.0025 \\
\hline Patch $\times$ year & 6 & 0.60 & 2.85 & 0.009 \\
\hline
\end{tabular}

Graminoid Cover $\left(r^{2}=0.31\right)$ :

\begin{tabular}{|l|l|l|l|l|}
\hline SOURCE & ḊF & SUM OF SQUARES & F & P \\
\hline Year & 3 & 0.15 & 1.36 & 0.25 \\
\hline Site & 2 & 10.36 & 139.48 & 0.0001 \\
\hline Patch size & 2 & 2.78 & 37.43 & 0.0001 \\
\hline Burn severity & 3 & 7.69 & 69.07 & 0.0001 \\
\hline Slope & 1 & 0.06 & 1.51 & 0.22 \\
\hline Aspect & 2 & 1.01 & 13.66 & 0.0001 \\
\hline Site $\mathrm{x}$ year & 6 & 0.66 & 2.97 & 0.007 \\
\hline Bum $\mathrm{x}$ year & 9 & 0.56 & 1.69 & 0.09 \\
\hline Patch $\mathrm{x}$ year & 6 & 0.13 & 0.60 & 0.73 \\
\hline
\end{tabular}

Shrub Cover $\left(r^{2}=0.13\right)$ :

\begin{tabular}{|l|l|l|l|l|}
\hline SOURCE & DF & SUM OF SQUARES & F & P \\
\hline Year & 3 & 0.02 & 0.43 & 0.73 \\
\hline Site & 2 & 0.56 & 19.07 & 0.0001 \\
\hline Patch size & 2 & 0.80 & 27.38 & 0.0001 \\
\hline Burn severity & 3 & 2.78 & 63.63 & 0.0001 \\
\hline Slope & 1 & 0.007 & 0.46 & 0.50 \\
\hline Aspect & 2 & 0.03 & 0.99 & 0.37 \\
\hline Site $x$ year & 6 & 0.26 & 2.95 & 0.007 \\
\hline Burm $x$ year & 9 & 0.13 & 1.00 & 0.44 \\
\hline Patch $x$ year & 6 & 0.06 & 0.69 & 0.65 \\
\hline
\end{tabular}

Most of the variability in the percent cover of tree seedlings (primarily lodgepole pine Pinus contorta var. latifolia) was due to differences between study sites (Table 1), with values being greatest at Cougar Creek (Figure 2). Tree seedling cover was greatest in crown fire and severe surface burns, which led to stand replacement, and lowest in light surface burns (Figure 2). In the stand-replacing burns, percent cover of tree seedlings increased between 1990 and 1993 by nearly $400 \%$ at Cougar Creek. The Yellowstone Lake site had the lowest percent cover of tree seedlings.
Percent cover of forbs was largely explained by differences between sites, with the Yellowstone Lake site having the greatest forb cover (Figure 3, Table 1). Forb cover at Fern Cascades and Yellowstone Lake increased through time, but interestingly, forb cover did not change significantly at Cougar Creek through time. In contrast, graminoid cover (Figure 4) increased through time at Cougar Creek, but not at Fern Cascades or Yellowstone Lake. Graminoid cover was greatest at Cougar Creek and comparable at Fern Cascades and Yellowstone Lake. Graminoid cover also tended to be lowest in crown fire areas and greatest in areas of light surface burn (Figure 4). In areas of light surface burn, graminoid cover is similar among all sites, ranging from ca. $15-20 \%$.

Shrub cover varied primarily with burn severity, patch size, and study site (Table 1) and did not show changes through time. However, there was a significant interaction effect between site and year (Table 1).

Across all study sites and burn severity classes, biotic cover varies as a function of patch size. While total biotic cover increased over time among all patch sizes, the small patches had the greatest total cover and the large patches the least (Figure 5). Total forb cover followed the same trend, and graminoid cover was greatest in the small patches and comparable in the large and moderate patches (Figure 5). The cover of tree seedlings, however, exhibited the opposite trend, being greatest in the large patches and lowest in the small patches (Figure 5).

\section{$\downarrow \quad$ DISCUSSION}

Variation in total biotic cover reflects the inherent productivity of the study sites and differences in the plant community composition as well as the effects of the fire. The Yellowstone Lake and Cougar Creek areas exhibit comparable total biotic cover, but for different reasons. The Lake site is located at high elevation on relatively fertile andesite-derived soils, and nearly all of the prefire lodgepole pine bore open cones (Tinker et al., in press). Forbs now contribute substantially to total biotic cover in this area but tree seedling cover is extremely low. In contrast, Cougar Creek is at low elevation and has rhyolite-derived soils of lower 

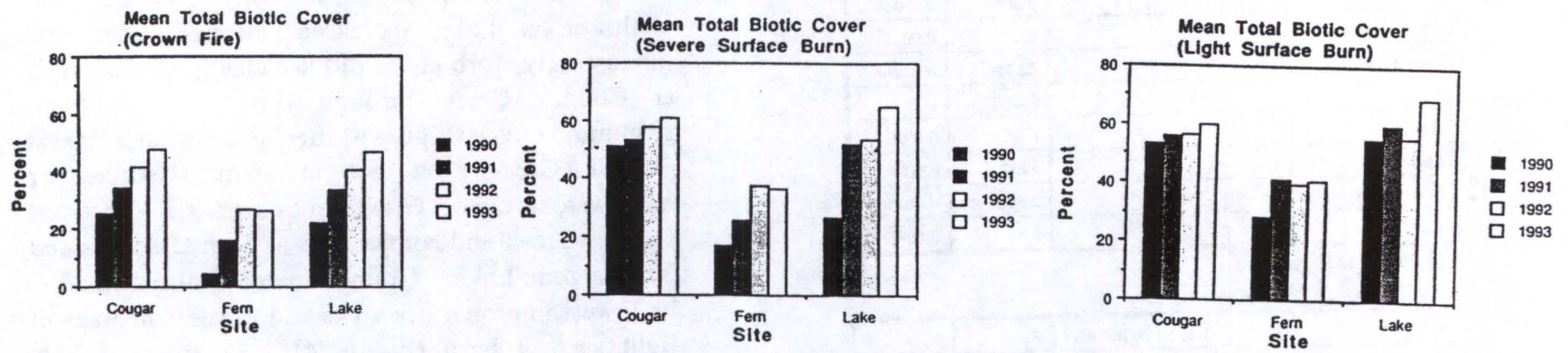

Figure 1. Mean total biotic cover in burned patches of Yellowstone National Park.
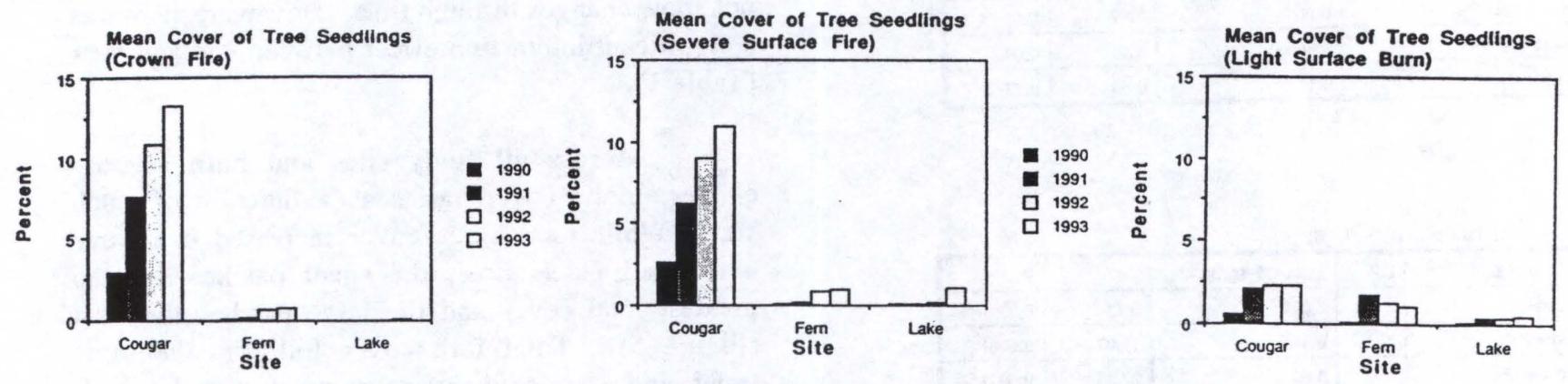

Figure 2. Mean cover of tree seedlings in burned patches of Yellowstone National Park.
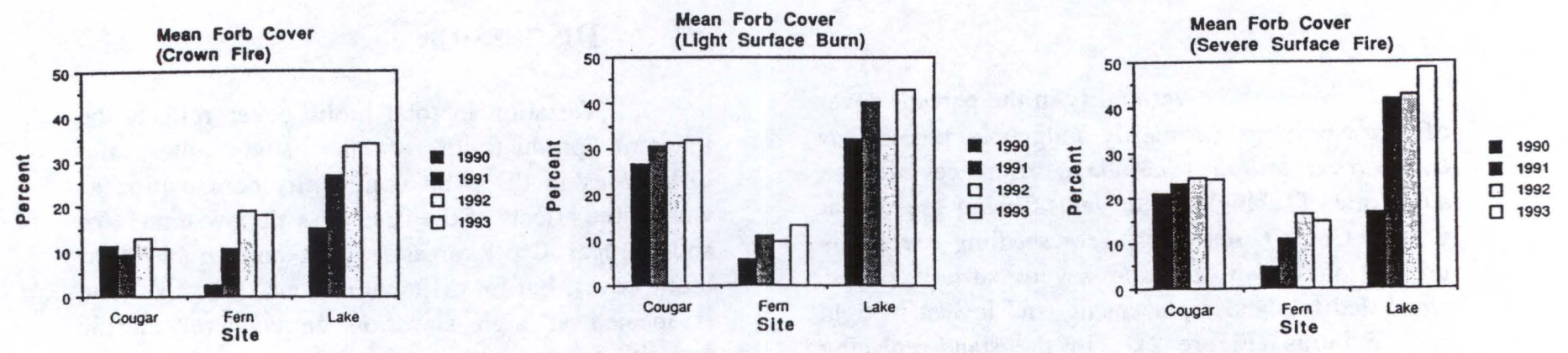

Figure 3. Mean forb cover in burned patches of Yellowstone National Park. 

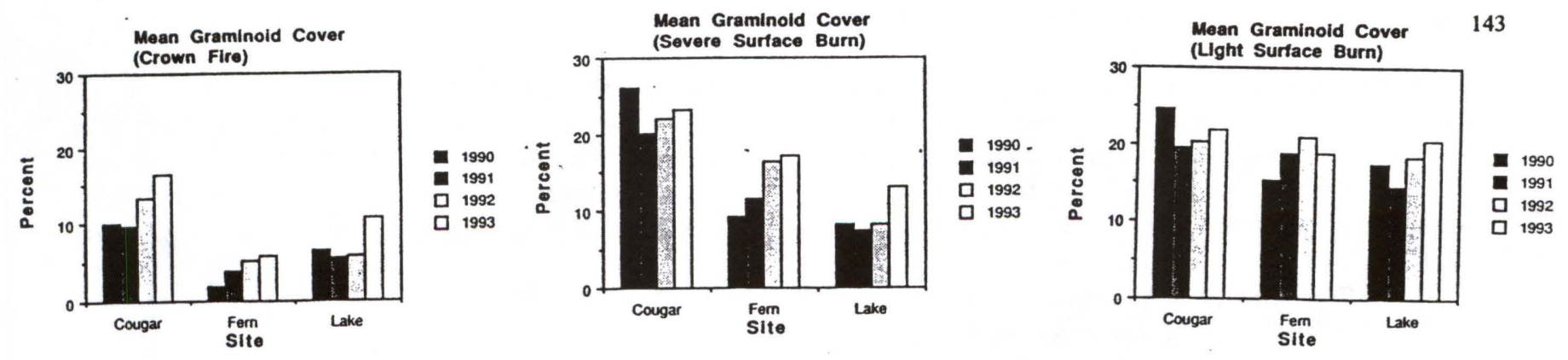

Figure 4. Mean graminoid cover in burned patches of Yellowstone National Park.
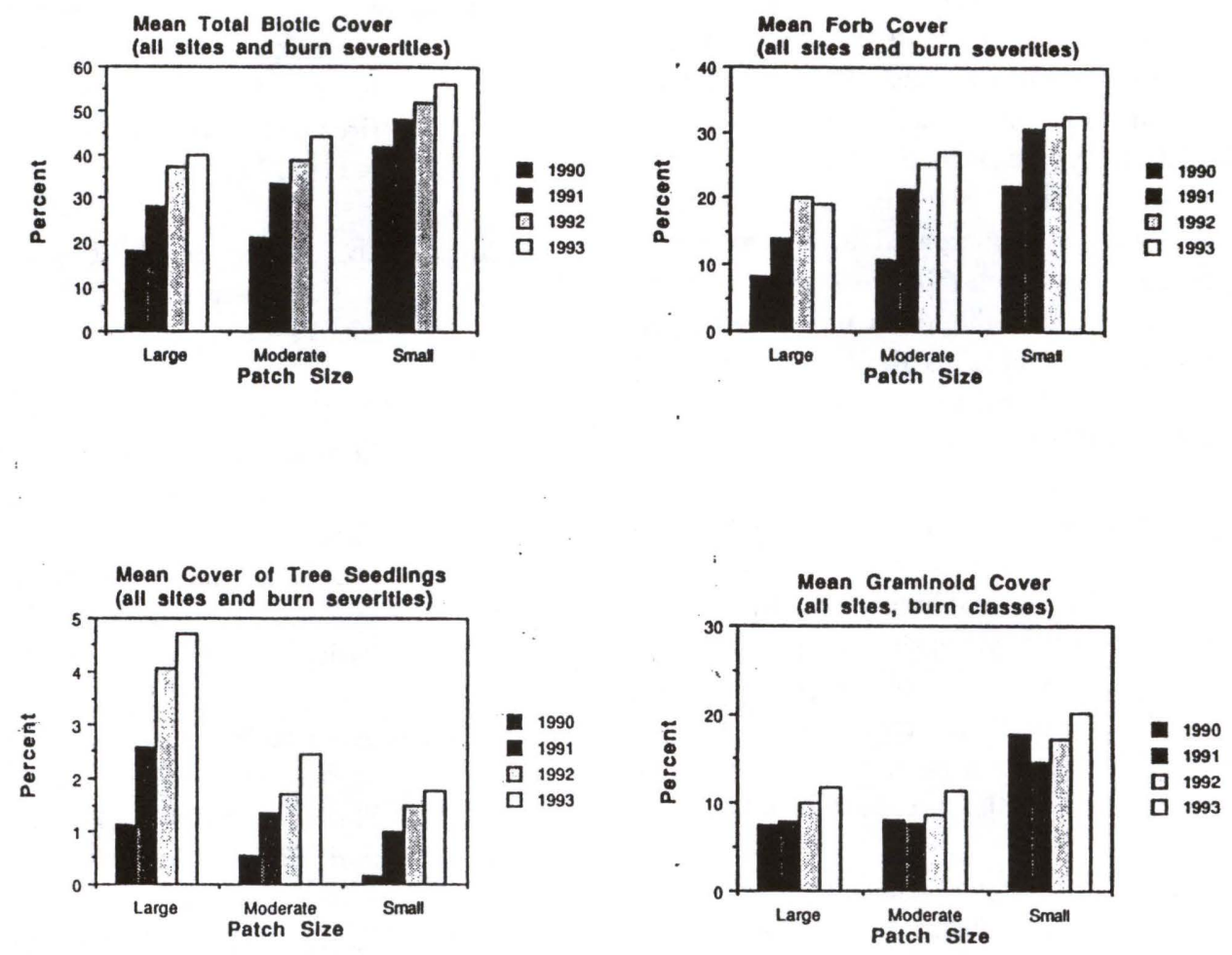

Figure 5. Mean plant cover aggregated over all sites and burn severity classes in burned patches of Yellowstone National Park.

fertility. Pre-fire lodgepole pine stands in this area were characterized by high serotiny (Tinker et al., in press), and tree seedling cover at Cougar now is an order of magnitude higher than observed at Yellowstone Lake or Fern Cascades. However, forb cover at the Cougar site is relatively low. The Fern Cascades site is on high-elevation rhyolite and probably is the least fertile of the three sites; total biotic cover is lowest at this site.
The strong effect of burn severity on shrub cover (Table 1) and the lack of any significant changes through time probably reflects the slowgrowing habit of Vaccinium scoparium, the dominant shrub. We have never observed a Vaccinium scoparium seedling in either the burned or unburned forests in Yellowstone, although we have observed berry production in the plants and the seeds will germinate in the laboratory. Thus, all post-fire 
regeneration to date appears to be vegetative growth. Hence, the plants tend to occur only in areas where they occurred prior to the fire, and their abundance is then strongly influenced by the fire severity experienced locally.

The greater total biotic cover in small patches probably can be explained by the fact that small patches generally contain a lower proportion of severely burned area than do larger patches (Turner et al., in press). This results in increased survival and post-fire resprouting of plants that were present before the fire (Anderson and Romme 1991). Moreover, because the small patches are surrounded within $100-200 \mathrm{~m}$ by unburned or lightly burned forest, the amount of light reaching the forest floor probably is lower when compared to the moderate and large patches. The more rapid reestablishment of herbaceous vegetation and the lower light intensity in small patches may combine to limit the growth of tree seedlings, thus explaining the lower cover of tree seedlings in the smaller patches.

We observed large changes from year to year in our permanent plots during the first three years after the 1988 fires, but since 1992 the rate of change in cover and density has slowed considerably. We plan to resample a portion of the plots in each patch during the 1994 field season, and then to continue resampling all or a portion of the plots at intervals of 2-5 years for the next few decades.

It is premature to give a definitive answer to the question whether the effects of large fires differ in important qualitative ways from those of small fires. Our results to date indicate that there are significant differences in the post-fire recovery of large vs small patches (e.g., cover of herbs vs cover of tree seedlings) and in relation to burn severity (e.g., the differential cover of shrubs) However, these differences attributable to fire size and intensity may be overshadowed by site-specific differences in microclimate, soils, and prefire community structure.

\section{$\checkmark \quad$ ACKNOWLEDGMENTS}

This research was supported by grants from the National Science Foundation. Housing and logistical support were provided by the University of Wyoming - National Park Service Research Center. The Research Division, Ranger Division, and
Geographic Information Systems Laboratory of Yellowstone National Park provided assistance in many different ways. Without the help and encouragement of many individuals within these organizations, our research would not have been possible.

\section{Literature Cited}

Anderson, J.E., and W.H. Romme. 1991. Initial floristics in lodgepole pine Pinus contorta forests following the 1988 Yellowstone fires. International Journal of Wildland Fire 1:119-124.

Christensen, N.L., et al. 1989. Interpreting the Yellowstone fires of 1988. BioScience 39:678-685.

Despain, D.G., A. Rodman, P. Schullery, and H. Shovic. 1989. Burned area survey of Yellowstone National Park: the fires of 1988. Unpublished report, Division of Research and Geographic Information Systems Laboratory, Yellowstone National Park, Wyoming.

Dirks, R.A., and B.E. Martner. 1982. The climate of Yellowstone and Grand Teton National Parks. Occasional Paper No. 6, National Park Service, Washington, D.C.

Halpern, C.B. 1989. Early successional patterns of forest species: interactions of life history traits and disturbance. Ecology 70:704-720.

Keefer, W.R. 1972. Geologic story of Yellowstone National Park. Geological Survey Bulletin No. 1347. U.S. Government Printing Office, Washington, D.C.

Malanson, G.P. 1984. Intensity as a third factor of disturbance regime and its effects on species diversity. Oikos 43:411-413

Miller, T.E. 1982. Community diversity and interactions between the size and frequency of disturbance. American Naturalist 120:533-536. 
Romme, W.H., and D.G. Despain. 1989. Historical perspective on the 1988 Yellowstone fires. BioScience 39:695-699.

Rowe, J.S. 1983. Concepts of fire effects on plant species and individuals. Pages 135-154 in: R.W. Wein and D.A. MacLean, editors, The role of fire in northern circumpolar ecosystems. SCOPE 18. John Wiley \& Sons, New York.

Tinker, D.B., W.H. Romme, W.W. Hargrove, R.H. Gardner, and M.G. Turner, in press. Landscape-scale heterogeneity in lodgepole pine serotiny. Canadian Journal of Forest Research.
Turner, M.G., Y. Wu, S.M. Pearson, W.H. Romme, and L.L. Wallace. 1992. Landscape-level interactions among ungulates, vegetation, and large-scale fires in northern Yellowstone National Park. Pages 206-211. In: Plumb, G.E., and H.J. Harlow (editors), 16th Annual Report of the University of Wyoming - National Park Service Research Center, Laramie, Wyoming.

Turner, M.G., W.W. Hargrove, R.H. Gardner, and W.H. Romme, in press. Effects of fire on landscape heterogeneity in Yellowstone National Park, Wyoming. Journal of Vegetation Science. 